\title{
Organic Fertilizers Use and Application for Cereal Crop Production in Ethiopia
}

\author{
Zelalem Addis \\ South Agricultural Research Institute Bonga Agricultural Research Center, P.O.Box101, Bonga
}

\begin{abstract}
Different relevant studies have been held across the county parts or regions to assess the effect different organic fertilizers like compost, farm yard manure, green manure, crop residue and biogas slurry application and use in experiment field and smallholder farming without upsetting their usual living. Results supposed to the benefit of farmers and come up with a policy briefing that policy makers give a better support for its implementation. The experiments conducted in different regions by different researchers like Maichew District of Tigray Region by Hailu Araya, Gozamen Woreda Eastern Gojam Amhara Region by Tadesse Dejene, Haraghe zone Oromia region Easten Ethiopia by Zelalem Bekeko and Sirinka Earstern Amara rgegion by Abebe Getu and Yalemtshay debebe in Sebeta Oromia Region indicated that the application compost Farm yard manure green manure and Biogas slurry enhances different crop production and productivity by improving of soil physical and chemical property and also bring additional benefit in terms of minimizing inorganic fertilizers cost. Therefore this visualized or tell us for the future as country level promoting of organic fertilizers in well-organized form is very important to enhance cereal crop productivity and there quality by improving soil and soil fertility issues.
\end{abstract}

Keywords: Organic fertilizers, Cereal crops

DOI: $10.7176 / J N S R / 9-10-03$

Publication date:May $31^{\text {st }} 2019$

\section{INTRODUCTION}

Agriculture in Ethiopia has long been a priority and focus of national policy such as Agricultural Development Led Industrialization (ADLI) and various large scale programs such as the Plan for Accelerated and Sustained Development to End Poverty (PASDEP) (Alemayehu, 2008). However, the sector is characterized by low productivity and the prevalence of a fragmented smallholder/subsistence farmer population that is relegated to highly degraded/marginal land (WB, 2010). Low productivity can be attributed to limited access by small farmers to agricultural inputs, financial services, improved production technologies, irrigation and agricultural output markets and, more importantly, to poor land management practices that have led to severe land degradation in some areas. Therefore, the sector is also characterized by low input-low output and labor-intensive rain fed farming systems reliant on the use of animal power. Ethiopia faces a wider set of soil fertility issues beyond inorganic fertilizer use which has historically been the major focus for extension workers, researchers, policymakers and donors. These issues interact and include loss of soil organic matter, macronutrient (N, P and $\mathrm{K}$ ) and micronutrient $(\mathrm{Fe}, \mathrm{Mn}, \mathrm{Zn}, \mathrm{Cu}, \mathrm{B}, \mathrm{Mo}$ and $\mathrm{Cl}$ ) depletion, topsoil erosion, acidity, salinity and deterioration of other physical soil properties (Gete et al., 2010).

In terms of soil nutrients and fertility, Ethiopia has one of the highest rates of nutrient depletion in Sub-Sahara African. The estimated annual nationwide loss of phosphorus and nitrogen resulting from the use of dung and crop residues for fuel is equivalent to the total amount of commercial fertilizer use. However; use of organic fertilizer such as animal manures, human waste, food wastes, backyard wastes, sewage sludge and composts has long been recognized in agriculture as beneficial source for plant nutrients and thereby improving, yield of crops. Traditional composting of organic wastes has been known for many years but new methods of thermophilic composting have become much more popular since it eliminates some detrimental effects of organic wastes in the soil and it is also cost effective and environmentally sound process for treatment of many organic wastes (Hoitink and Keener, 1993). Many researchers stated that unavailability and low quality of organic materials, and shortage of labour constrained the use of organic materials for soil fertility management in the tropics.

However, considerable amounts of organic materials are wasted without proper use especially in humid and sub-humid agro-ecosystem of Ethiopia. These locally available organic materials such compost, crop residues, FYM, appropriate crop rotation, and improved fallow are used based on socio-economic circumstances of farming communities, the investment in organic fertilizers processing and application is not more than the cost of inorganic fertilizers. The sole application of either organic or inorganic fertilizers on degraded soils can hardly increase crop yield in the tropics (Palm et al., 1997). So long as agriculture remains a soil-based industry, there is no way that required yield increases of the major crops can be attained without ensuring that plants have an adequate and balanced supply of nutrients (Gruhn et al., 2000). This call for alternative cropping systems that address key aspects of nutrient management such as increasing plant-available nutrients and soil organic matter by organic fertilizers . 


\section{Cereal Crop production}

Among the major cereal crops, teff, wheat, maize, barley and sorghum represent 95 percent of total cereal planted area and 96 percent of total cereal production. Since the 1960s, teff has accounted for the largest share of cereal cultivated area. However, the teff share has been declining gradually over the last four decades to make room for other cereals, mainly maize, whose share increased by almost 8 percent over the same time period and Wheat also experienced a slight increase, while barley decreased about 3 percent and sorghum and other cereals experienced slight changes within the same time period (Taffesse et al., 2011).

\section{Organic fertilizers use and application in cereal production}

Various studies in Ethiopia have also shown the importance of Organic Fertilizer (OF) in improving soil productivity (Wakene et al., 2001).Organic Fertilizer can serve as an alternative practice to mineral fertilizers by improving soil structure (Dauda et al., 2008) and microbial biomass. However; its sources such as cow dung and crop residues have been declined from time to time mainly due to their demand for domestic energy consumption and removal for animal feeding. In addition, use organic matter is also limited due to lack of awareness and technical knowledge, high labor demand for preparation, its requirement in large quantities due to low nutrient contents and slow release as well as its tediousness for transporting to crop fields.

Jones (1971) found that annual applications of 7 up to 8 ton per hectare farm yard manure (FYM) are needed to maintain a $1 \%$ soil Organic Matter (OM) level in sandy top soils at Samaru, Nigeria which indicated a need for bulk application of OM to soils. Due to the continuous increase in the cost of inorganic fertilizers, application of inorganic fertilizers is becoming difficult to be afforded by small and marginal farmers in Ethiopia. Because of this use of sole organic fertilizer or combined with inorganic fertilizer on nutrient depleted soils can increase crop yields in Ethiopia (Wakene et al., 2007).

To sustain high crop yields without deteriorating soil fertility, it is important to work out optimal combination of inorganic fertilizers and Organic fertilizer in cropping system (Rekhi et al., 2000) as the interaction of organic and inorganic fertilizers improves the absorption, distribution and function of another nutrient. Affordable, resilient, renewable and low cost sources of plant nutrients from Organic fertilizer supplement and complement chemical fertilizers. Adequate soil fertility for sustained crop yields can be obtained with the combined use of organic and inorganic fertilizers.Heluf (2002) reported that integrated use organic and inorganic fertilizers are pertinent enough to improve plant nutrients under the Ethiopian conditions.

\subsection{Advantage of Using Organic Fertilizer over Inorganic Fertilizers}

Maintenance of high crop yield under intensive cultivation is possible only through the use of fertilizers. Inorganic fertilizers are usually rather expensive for the low income and small scale farmers. Organic manures such as cow dung, poultry manure, crop residues and biogas slurry in liquid and composted form can be used as an alternative for the inorganic fertilizer (Dong and Li, 2010). Nutrients contained in organic manures are released more slowly and are stored for a longer time in the soil, thereby ensuring a long residual effect, supporting better root development, leading to higher crop yields even better than the yield of inorganic fertilizer (Eadwards et al., 2007). Soil fertility status is improved by activating the soil microbial biomass. To meet crops' nutrient supply, organic fertilizers even if, they required in large quantities there is no adverse side effect of excessive application of organic manure to the soil since the excess of nutrients present in it becomes available for subsequent crops due to its residual effect.

On the contrary, if inorganic fertilizers are applied in very large amount, it is detrimental to the soil condition, thereby affecting crop production. Besides, it will also have adverse indirect impact on food chain through land, water, and air pollution resulting from leaching, run off, and spraying respectively (Menale et al., 2009). Application of organic manures sustains cropping systems through better nutrient recycling and plays a direct role in plant growth as a source of all necessary macro and micronutrients in available forms during mineralization, thereby improving both the physical and bio chemical properties of the soil (Menale et al., 2009).

\subsection{Compost}

Generalized definition of compost is a recycled or decomposed organic waste from different crop residues, animal manure and wastes and sludge being stabilized by the work of macro- and micro-organisms through aerobic, semiaerobic and anaerobic biological processes inside a pit or on surface (Elias, 2002).

\subsubsection{Quality and Application rate of Compost}

Compost is becoming widely used by many farmers in the Sub-Saharan Africa to improve soil fertility and crop production (Mugwe et al., 2007). By 1995 compost has been expanded into 11 percent in Southern Ethiopia (Elias, 2002) while by 2005 it has been using by about 25 percent farmers in Tigray (SSNC, 2008). Dry matter application rates of compost are variable from the lowest 10 and 11.2 t.ha-1 .yr-1 (Smiciklas et al., 2008). The equivalent amounts of macronutrient for the 10 and 11.2 t.ha-1.yr-1 compost as the lowest application is vary very much from 60,13 and $17 \mathrm{~kg}$. ha-1 of NPK respectively while the highest application of compost, which is 134 t.ha-1 compost, 
gives 1,478 (N), $540(\mathrm{P})$ and $940(\mathrm{~K}) \mathrm{kg}$.ha-1 (Table 1). These applications are much higher than the usual macronutrient applications through organic and inorganic fertilizers.

Table1.Compost application rates (t.ha-1.yr-1) and their corresponding nutrients (kg.ha-1.yr-1)

\begin{tabular}{llllll}
\hline Application rate t/ha & \multicolumn{2}{l}{$\begin{array}{l}\text { Nutrient application } \\
\text { kg.ha-1.yr-1 }\end{array}$} & & Place and soil type & Authors \\
\cline { 2 - 3 } & $\mathrm{N}$ & $\mathrm{P}$ & $\mathrm{K}$ & & \\
10 & 60 & 13.1 & 16.7 & India & Manna et al., 2001 \\
11.2 & 123.2 & 44.8 & 78.4 & 1llinos ,USA & Smiciklas et al, 2008 \\
16.0 & 143 & - & - & Australia-Luvisols & Erhart et al., 2007 \\
22.4 & 246.4 & 89.6 & 156.8 & 1llinos ,USA & Smiciklas et al, 2008 \\
23.0 & 205 & - & - & Australia-Luvisols & Erhart et al., 2007 \\
33.6 & 369.6 & 134.4 & 235.2 & 1llinos ,USA & Smiciklas et al, 2008 \\
44.8 & 492.8 & 179.2 & 313.6 & 1llinos ,USA & Smiciklas et al, 2008 \\
67.2 & 739.2 & 268.9 & 470.4 & 1llinos ,USA & Smiciklas et al, 2008 \\
134.4 & 1478.4 & 537.6 & 940.8 & 1llinos ,USA & Smiciklas et al, 2008 \\
\hline
\end{tabular}

Source: Hailu, 2010.

Studies show composts contain about 12-20 percent organic carbon (Asmelash, 2001), which are sources of energy for bacteria, fungi, earthworms and other organisms in the soil. They break-down dead plant and animal remains by releasing carbon dioxide, water and mineral salts, including nitrates, phosphates, etc., which are the nutrients for growing plants (Asmelash, 2001). The nitrogen content of compost is reported as high as $15.3 \mathrm{~g} . \mathrm{kg}^{-}$ ${ }^{1}$ (Wahba, 2007).Carbon: Nitrogen $(\mathrm{C} / \mathrm{N})$ ratio $<21$ is compost maturity indicator (Getinet et al., 2008). From a study by Manna et al., (2001) in the semi-arid tropics of India $\mathrm{C}$ : $\mathrm{N}$ ratios of 8-22. Compost with a higher $\mathrm{C}$ : $\mathrm{N}$ ratio is not recommended for application because $\mathrm{C}: \mathrm{N}$ ratio $>15$ is an indication of limited $\mathrm{N}$ availability due to immobilization.

In matured compost the lowest $\mathrm{C}$ : $\mathrm{N}$ ratio, below 6-7 (Gutser et al., 2005) is an indication of materials to be humified and stable. They are suitable for field application, Improving $\mathrm{N}$ and $\mathrm{C}: \mathrm{N}$ ratio of compost is related to the proportion of the green plants and dry materials used for the compost-making. The optimum $\mathrm{C}$ : N proportion of different composting materials is 30:1 (Getinet et al., 2008). Because composting has high carbon materials additional nitrogen (mineral fertilizer) may be required to reduce the $\mathrm{C}: \mathrm{N}$ ratio to the optimal range. It facilitates the establishment of micro-organisms for the quick decomposition of biomass into compost. Generally dry materials (woody materials or dead leaves) have higher $\mathrm{C}: \mathrm{N}$ ratios while green materials usually have lower $\mathrm{C}: \mathrm{N}$ ratios. This is because the dry, coarse materials such as straw, wood chips, etc. are high in $\mathrm{C}$ and low in $\mathrm{N}$ while the green materials such as grass clippings, fresh plant material, kitchen scarps and manure, are high in nitrogen and low in carbon. Animal wastes are also more N rich than plants (Cyber-north, 2004).

\subsubsection{Compost Production capacity}

The compost production capacity of farmers varies very much. It varies from farmer to farmer mainly dependent on the animal holding (Tulema et al., 2007). This is because animal feed waste and animal manure are available best to the farmers who own cattle (Kikafunda et al., 2001). According to Manyong et al., (2001) more livestock holding encourages families to use organic manure and owning domestic animals are common in Africa. The availability of biomass in Ethiopia is estimated to $22.7 \times 10^{6}$ t.yr $^{-1}$ of dry manure, $12.7 \times 10^{6}$ t.yr $^{-1}$ crop-residue and various other organic by-products (Tulema et al., 2007). While the study by Devi et al., (2007) reported that recyclable resources in Ethiopia are abundant. They estimated the total amount available as $1.6 \times 10^{11} \mathrm{t}_{\mathrm{yr}} \mathrm{r}^{-1}$ (compost/vermicomposting), $8.5 \times 10^{9}$ t.yr $r^{-1}$ (poultry manure) and $1.8 \times 10^{10}$ t.yr $^{-1}$ (FYM).

While the required amounts for the total agricultural land per year is $3.25 \times 10^{10} \mathrm{t}_{\mathrm{yr}} \mathrm{yr}^{-1}$

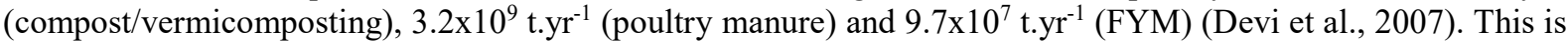
mainly because Ethiopia is the highest in livestock population in Africa (Zinash, 2001). Biomass availability in moisture stress areas is dependent in the biomass management. For example, farmers keep manure accumulated in cattle pen until it is cleaned or used for composting (Miner et al., 2001). Manure management increases not only the quantity but also the quality of the manure (Lekasi et al., 2001). But the production capacity varies based on the animal holding. However, so far the production capacity of compost is not studied at family level.

\subsubsection{Compost application by smallholder farmers}

The rate of application of organic manure differs according to the climatic conditions of the area. In the western part of Ethiopia the recommended application rate is 8-12 t/ha but in other areas applying 3.5-6.0 t/ha can give good yield (Fentaw, 2010). The average amount of compost application ranged from 5-15 t/ha, depending on availability of materials (Menale et al, 2009).According to Hailu Araya (2010) Over $88 \%$ of the farmers in Tigray region Maychew use compost. About 39 percent of them produce between 1 and $2 \mathrm{t}$ compost annually (Figure 1). The average cultivated landholding of the area is 0.8 hectare per family, which is fragmented into two or more pieces. The average amount of compost sieved and weighed from one $1.0 \mathrm{mx} 1.5 \mathrm{mx} 1.5 \mathrm{~m}$ pit is $800 \mathrm{~kg}$ i.e., $16-18$ Qumta (a traditional quantity measurement sack equivalent with $50 \mathrm{~kg}$ ). Usually it is used in one plot of land, 
which is called Tsimdi/Kert (equivalent with 0.25 hectare).

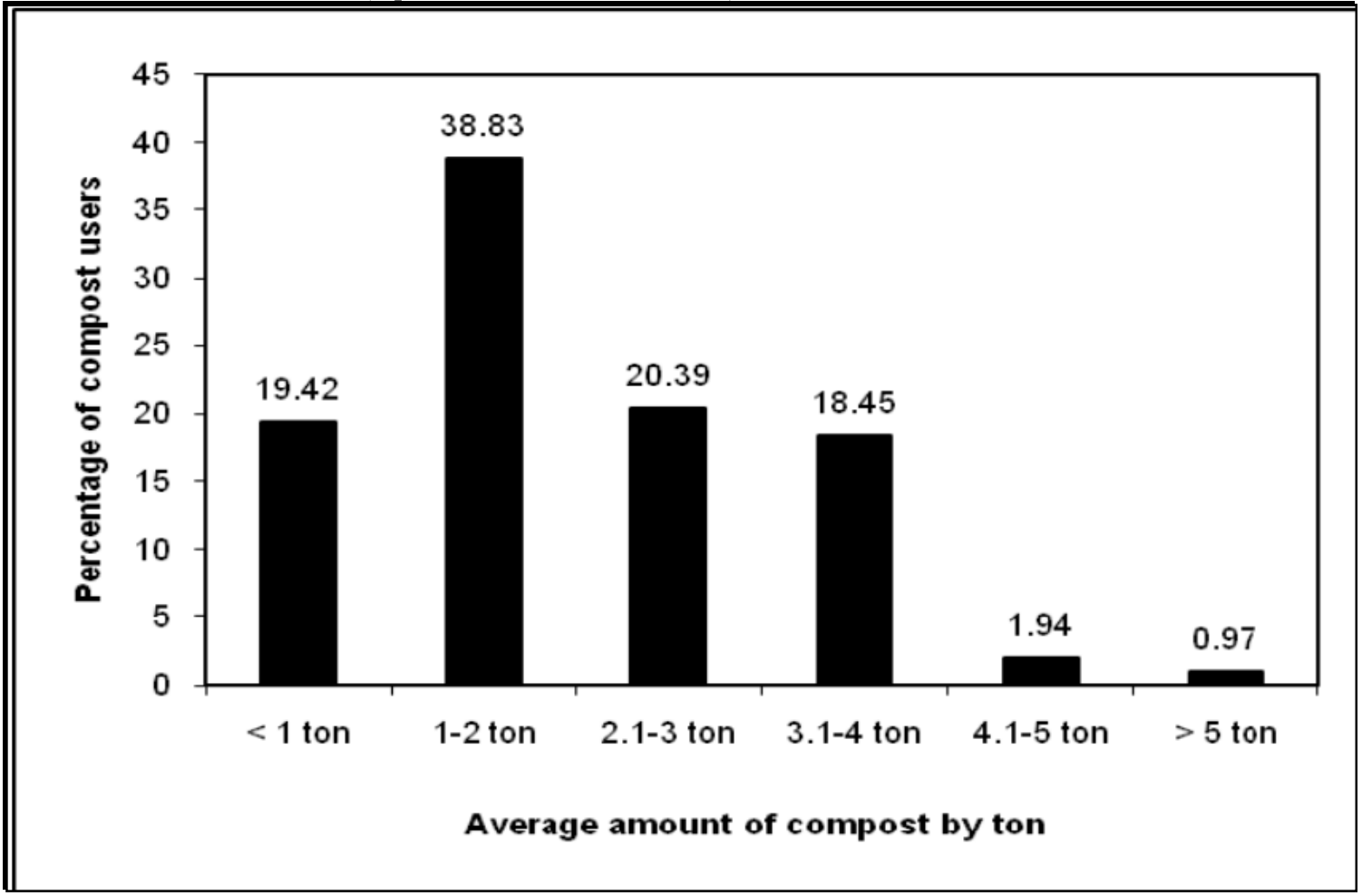

Source: Hailu , 2010.

Figure1. Percentage of farmers $(n=103)$ who use compost and amount of compost produced.

However, the amount of compost applied per unit area varies based on the type of the soil and crop. But generally more compost is applied in sandy soil and for higher plants, while less amount of compost is applied in clay soil and for smaller plants. For example, when a field is sown with teff, which is a very small type of crop, the application of compost is $2.8 \mathrm{t}^{\mathrm{h}} \mathrm{ha}^{-1}$ in clay soil and $4.8 \mathrm{t}^{\mathrm{ha}} \mathrm{a}^{-1}$ in sandy soil. On the other hand when a field is sown with barley, wheat or finger millet higher amounts of compost is applied than they apply for teff (Table2). According to the farmers this is important application amount because they are getting better yield without lodging problem in the different crops.

Over 39 percent farmers used mix compost and animal manure with mineral fertilizer. 24 percent of the farmers prepare and use only compost and 13.5 percent use only animal manure in their fields. There are only 13.5 percent farmers who use mineral fertilizer alone in their fields. About 10 percent they do not use any type of input in their farms. It is because they have fertile fields, which does not need any input to be applied (Hailu Araya, 2010).

Table 2.Average amount of compost applied per crop and soil type (t.ha-1.yr-1).

\begin{tabular}{cccc}
\hline Crop type & clay & reddish & Sandy \\
\hline Teff & 2.8 & 3.2 & 4.8 \\
Barley , wheat ,finger millet & 3.2 & 3.4 & 5 \\
Maize /sorghum & 3.4 & 4 & 6 \\
Legumes & \multicolumn{3}{c}{ No application } \\
\hline
\end{tabular}

Source: Hailu, 2010.

\subsubsection{Effect of Compost on Yield of Cereals}

Compost enhances soil fertility, soil structure and water storage capacity for two or more years, unlike inorganic fertilizer (Fentaw, 2010). Jagadeeswari and Kumaraswamy (2000) noted that use of composts with mineral fertilizer increased yield and production of wheat, green beans, gram and rice. Grain and straw yields of rice were significantly higher in amendments that received compost application with NPK than in no compost with NPK amendments, thereby highlighting the beneficial effects of compost to increase the crop yield.

The study conducted ada'a district Eastern Shewa Oromia region by Genizeb Ayaye (2015) indicated that ; The grain yield value of bread wheat $666.67 \mathrm{gm}^{-2}$ or $66.67 \mathrm{Qt} / \mathrm{ha}$ was recorded in the application of dry matter compost along with inorganic fertilizers. However, the lowest grain yield $\left(260 \mathrm{gm}^{-2}\right.$ or $\left.26 \mathrm{Qt} / \mathrm{ha}\right) \mathrm{was}$ obtained under control field or plot .Similar Research which conducted by Hailu Araya in Tigray region grain yields of teff and barley from plots applied with mineral fertilizer and 6.4 t.ha ${ }^{-1} \cdot \mathrm{yr}^{-1}$ compost show they are 
significantly higher than the 3.2 t.ha-1.yr ${ }^{-1}$ compost application and the control plots.

But there is no significant difference between the 6.4 t.ha ${ }^{-1}$ compost and the mineral fertilizer applied plots. The grain yield between 3.2 t.ha-1. $\mathrm{yr}^{-1}$ compost and control plot indicated that compost application is better than the control plots. Other findings of Getachew et al. (2012) also revealed that efficient management and utilization of organic nutrient sources and the required inorganic fertilizers in correct balance may contribute to longer-term sustainability of agricultural productivity and an integrated farming system in the highlands Ethiopia, where soil erosion is serious and the resultant soil fertility depletion is alarming. This shows that the potential for continuous crop production on these soils is very limited in the absence of soil amendments or use of organic fertilizers.

\subsection{Crop residue}

Crop residues have a number of functions. When left in the field after grain harvesting, crop residues play a significant role in nutrient cycling, soil and water conservation, maintenance of favorable soil properties, and enhance subsequent crop yields. Other benefits of retaining crop residues on the soil surface include an increase of organic matter and nutrient levels, moderation of soil temperature and increased soil biological activity, all of which are important for sustaining crop production.

Crop residues are also used for other purposes, such as to provide vital livestock feeds during long dry seasons, fuel and construction material (Latham, 1997). Use of crop residues as a soil amendment is often limited due to its obstacle to mechanical and hand tillage, negative effects on crop productivity arising from incidence and carryover of pests (Ferdu et al., 2002), diseases (Tewabech et al., 2002), allelopathy and short term nutrient deficiency (Ocio et al., 1991). For these reasons, much of crop residues are either fed to cattle or burnt.

When all crop residues are used as animal feed or removed for other purposes, the above mentioned soil related benefits are lost. As a result, sustaining soil productivity becomes more difficult. Crop residues contains large quantities of plant nutrients and, if properly managed and returned to the soil from which it was grown, could serve as an effective means of maintaining the organic matter and nutrient levels in soil. recycling of crop residues is especially important in developing like Ethiopia countries because: (i) the amount of the nutrients in crop residues are seven to eight times higher than the quantity of nutrients applied as fertilizers, (ii) crop residues is a source of trace elements which are absent in the commercial NPK fertilizers and (iii) organic and inorganic materials have a complementary role and their simultaneous use will ensure better crop yields.

Proper usage of crop residues could therefore result in less importation of chemical fertilizers with great savings in scarce foreign exchange. In most countries of Africa the nutrient balances of cropping systems are negative, with off take being greater than input, indicating that farmers are mining the soils. Larson et al. (1972) estimated that crop residues contain on average 40,10 , and $80 \%$ of the $\mathrm{N}, \mathrm{P}$, and $\mathrm{K}$ currently applied as fertilizer. For example a ton of maize residue contains $4-8 \mathrm{~kg} \mathrm{~N}, 1.5-1.8 \mathrm{~kg} \mathrm{P}, 13-16 \mathrm{~kg} \mathrm{~K}, 3.8-6.6 \mathrm{~kg} \mathrm{Ca}$, and $1.5-3.4 \mathrm{~kg} \mathrm{Mg}$. Residues of cereal crops comprise 60 to $75 \%$ of the total biomass production and have lower nutrient concentrations than the grain (Van Duivenbooden, 1992). Therefore, returning of them to the soil systems particularly, where no or low inputs are used, is essential in slowing down nutrient losses. However, crop residues by themselves are not enough to offset nutrient mining in sub-Saharan Africa. Crop residue management influences the availability of nutrients especially $\mathrm{N}$.

According to the study conducted by Tadesse Dejene (2011) In Gozamen Woreda Eastern Gojam Amhara Region, crop residues are commonly used for maintaining soil fertility and crop production in two ways. The first one is through shifting of animal feeding beds. In this case, farmers feed their cattle in different parts of their farm plots at different times. The common fodders of the cattle are grasses and straws or crop residues. While animals are feeding, there are remnants left on the soil and are through time biologically decomposed during farmland preparations. Shifting animal feeding places is duly important for addressing the whole parts of the farm plots, but because of its laboriousness, this method is mostly, applied in the nearby farmlands of the homesteads locally known as guaro, where livestock are usually kept.

The second method is shifting of threshing floors locally called Audima. In these both systems crop residues are mixed with soils during ploughing. However, farmers explained that it takes time to use crop residues as fertilizer since it requires a long period of time for decomposition to take place, but can be practiced in every farm plot. The farmers on the other side advise that crop residues negatively affect farmlands' productivity in different ways. For example residues like maize stalks and wheat residues can transmit crop diseases from place to place and enable these diseases to sustain their life until the next cropping season. If crop residues stay for a long period of time not decomposed, it will be comfortable for rodents breeding. Besides, they argue that since the most important sources of animal feeding are crop residues, using crop residues as fertilizer affects livestock production.

\subsection{Farm Yard Manure}

Animal manures are valuable sources of nutrients and the yield-increasing effect of manure is well established. Apart from the nutrients in manure, its effects on the improvement of soil organic matter, soil structure and the biological life of the soil are well recognized particularly at high rates of application in on-station trials. There is 
also some evidence that it may contain other growth-promoting substances like natural hormones and B vitamins (Leonard, 1986). Crop quality has also been improved by manure application (Pimpini et al., 1992).

When crop improvements with manure were greater than those attained with commercial fertilizer, response was usually attributed to manure supplied nutrients or to improved soil not provided by commercial fertilizer. It is also well known that the use of farmyard manure can reduce nutrient deficiency in soils. Koppen and Eich (1993) noted that $\mathrm{K}$ and $\mathrm{P}$ deficiencies were reduced when farmyard manure was applied, and with rising $\mathrm{pH}$ values, the Mn content of the soil declined. The potential of manure, especially poultry litter, to neutralize soil acidity and raise soil $\mathrm{pH}$ is less well known.

Application of animal manures to agricultural fields is a widely used in method of increasing soil organic matter, fertility and crop production (Wakene et al., 2005). Most solid livestock manures can be applied directly to crop fields or piled for composting. In organic farming, Nitrogen $(\mathrm{N})$ is supplied through organic amendments in the form of manure. Applying organic $\mathrm{N}$ fertilizer without prior knowledge of $\mathrm{N}$ mineralization and crop needs can result in nitrate nitrogen (NO3 N) leaching below the root zone and potential groundwater contamination (Debelle et al., 2001). Soil fertility depletion on smallholder farms is one of the fundamental biophysical root causes responsible for declining food production in eastern part of Ethiopia (Ararsa., 2012).

Highlands of Hararghe, eastern Ethiopia, where maize is grown among the major cereals in the high rainfall areas such as (Chiro, Doba, Tullo, Mesela, Gemechis, Kuni, Boke Habro and Daro Labu) soil fertility depletion is the number one problem stagnating crop productivity including maize Misganw (2014). Intercropping is widely used in this area by combining maize or sorghum with perennial crops like Chat (Chata edulis) which further exposes the soil to rampant nutrient degradation leading to poor crop yield ( Ararsa, 2012). Due to this Crop residues and FYM are used for maize production .the low rates of NP fertilizers used for maize production under farmers' conditions have aggravated the situation of soil fertility degradation and declining maize production. Consequently, training the farming community on the proper handling and use of FYM together with low rates of inorganic fertilizers taken as alternative solution for fertility management in Hararghe Misganw (2014) .

Supplying of nutrients from chemical fertilizers has got certain limitations and inherent problems. Further, these chemical fertilizers can supply only a few plant nutrients like nitrogen, phosphorus and potash and also they are becoming very expensive for resource poor farmers. Silvia et al. (2006) reported that non-inclusion of organic manures such as FYM, compost, green manures, etc. in the manurial schedule have resulted in the depletion of fertility status of the arable soils and their consequent degradation. Debelle et al. (2001) also reported organic manures, especially FYM, have a significant role for maintaining and improving the chemical, physical and biological properties of soils and in sustaining maize yield in western part of Ethiopia. They also reported that 10 ton/ha of FYM are statistically at equivalence with current agronomic recommendation of inorganic fertilizers $\mathrm{N}$ and $\mathrm{P}$ for maize.

Another study by Zelalem Bekeko (2013) at Haraghe Zone Oromia Region Easten Ethiopia indicated that that 10 tons/ha of FYM and $100 \mathrm{~kg} / \mathrm{ha} \mathrm{N}+100 \mathrm{~kg} / \mathrm{ha} \mathrm{P}$ showed no significant difference on maize grain yield but significantly differ from control Treatment (Table3). Wakene et al. (2005) also indicated that the urgency of using organic manure has been gaining ground in the wake of increasing cost of fertilizer with every passing year and certain other inherent limitations with the use of chemical fertilizers. FYM is the oldest organic manure used by man ever since he involved in farming. It has stood the test of time and is still very popular among the poor and marginal farmers.

It consists of litter, waste products of crops mixed with animal dung and urine.it contains all the nutrient elements present in the plant itself and returns these nutrients to the soil when it is applied to the field for the benefit of succeeding crop.

Table 3.Effect of enriched FYM on grain yield (mean values) of hybrid maize (BH-140) at Chiro, Western Hararghe from 2008 to 2011.

\begin{tabular}{|c|c|c|c|c|c|c|}
\hline \multirow[t]{2}{*}{ Treatment } & \multicolumn{6}{|c|}{ Mean grain yield of maize $(\mathrm{Kg} / \mathrm{ha})$} \\
\hline & Rep1 & Rep2 & Rep3 & Rep3 & total & mean \\
\hline Control (0 FYM and $0 \mathrm{~N}$ and $\mathrm{P})$ & 1563 & 1784 & 1586 & 1657 & 6590 & 1647.5 \\
\hline $10 \mathrm{t} / \mathrm{ha} \mathrm{FYM}+0 \mathrm{~N}$ and $\mathrm{P}$ & 6579 & 6934 & 6601 & 6496 & 26610 & 6652.5 \\
\hline $8 \mathrm{t} / \mathrm{ha} F Y M$ and $25 \mathrm{~kg} / \mathrm{ha} \mathrm{N}+20 \mathrm{~kg} / \mathrm{ha} \mathrm{P}$ & 5546 & 5955 & 6266 & 5661 & 23428 & 5857 \\
\hline $6 \mathrm{t} / \mathrm{ha} \mathrm{FYM}$ and $50 \mathrm{~kg} / \mathrm{ha} \mathrm{N}+40 \mathrm{~kg} / \mathrm{ha} \mathrm{P}$ & 5497 & 5353 & 4978 & 4854 & 20682 & 5170.5 \\
\hline $4 \mathrm{t} / \mathrm{ha} F Y M$ and $75 \mathrm{~kg} / \mathrm{ha} \mathrm{N}+60 \mathrm{~kg} / \mathrm{ha} \mathrm{P}$ & 7601 & 8155 & 8042 & 8836 & 32634 & 8158.5 \\
\hline $2 \mathrm{t} / \mathrm{ha} \mathrm{FYM}$ and $100 \mathrm{~kg} / \mathrm{ha} \mathrm{N}+80 \mathrm{~kg} / \mathrm{ha} \mathrm{P}$ & 7269 & 6837 & 6228 & 6340 & 26674 & 6668.5 \\
\hline $100 \mathrm{~kg} / \mathrm{ha} \mathrm{N}+100 \mathrm{~kg} / \mathrm{ha} \mathrm{P}$ & 6568 & 6821 & 7343 & 7256 & 27988 & 6997 \\
\hline Total & 4063 & 41839 & 41044 & 41100 & 164606 & 6858.58 \\
\hline
\end{tabular}

Source: Zelalem, 2013

The study conducted by Tadesse Dejene (2011) In Gozamen District Eastern Gojam Amhara Region indicated that the application of animal manures like fig (dry animal feces) combined with straws that are the remnants of 
plants used for animal fodders is important farmland management to be practiced. It also includes the byproducts of local food production processes like atela and others which are daily swept out of a house in dirt forms. This is applied by (93.85\%) of sample households (Table 4).According to Taddess (2011) most of the respondents or the farmers, used Farm yard manure with chemical fertilizers though they are not applied simultaneously. Unlike chemical fertilizers, manures are added to the soil long days ago before seeding either in the rainy or dry season. Nevertheless, it is mostly limited to farm plots which are nearer to homesteads, locally known as guaro, mainly due to long distance of the farm plots and this negatively affects soil fertility enhancement on farther farm plots.

Table 4. Indigenous soil fertility maintaining farmland management practices In Gozamen Woreda

\begin{tabular}{|c|c|c|c|c|c|c|}
\hline \multirow[t]{2}{*}{ variable } & \multicolumn{4}{|c|}{ Sample keble } & \multirow{2}{*}{$\begin{array}{l}\text { Total count } \\
(\mathrm{N}=130)\end{array}$} & \multirow{2}{*}{$\begin{array}{c}\text { Percent } \\
(\%)\end{array}$} \\
\hline & $\begin{array}{c}\text { Chertekel } \\
\text { kebele } \\
(\mathrm{N}=87)\end{array}$ & $\begin{array}{c}\text { Percent } \\
(\%)\end{array}$ & $\begin{array}{c}\text { May } \\
\text { Angetam } \\
\text { kebele } \\
(\mathrm{N}=43)\end{array}$ & $\begin{array}{c}\text { Percent } \\
(\%)\end{array}$ & & \\
\hline Manure & 83 & 95.4 & 39.4 & 90.6 & 122 & 93.8 \\
\hline Legumes Cropping & 46 & 52.8 & 24 & 55.81 & 70 & 53.85 \\
\hline Crop rotation & 85 & 97.7 & 42 & 97.67 & 127 & 97.69 \\
\hline Fallowing & 1 & 1.49 & 1 & 1.49 & 2 & 1.54 \\
\hline
\end{tabular}

Source: Tadesse, 2011

\subsection{Green manure}

Acknowledge the positive contributions of green manures or cover crops and allocated to grow is relatively small In Ethiopian only few legumes are integrated to the system. In the perennial-based farming systems the only most dominant legume in the cropping is common beans, intercropped with maize or grown sole as a second crop. However, cultivation of beans may not contribute much to soil fertility improvement mainly. because the crop is harvested by uprooting the whole plant as it needs to be stored by hanging bundles on a trellis and kept indoors to avoid sprouting (Eyasu, 2002); no residue is returned to the soil as pods and tops are fed to livestock with the stalk is used as feed or cooking fuel and beans has the least $\mathrm{N}$-fixing potential particularly in low $\mathrm{pH}$ soil with low $\mathrm{P}$ availability.

Legume green manure crops highly practicable especially in southern nations and nationality and peoples of Ethiopia for a short term fallow. The major biophysical criterion used for selection of cover crop species is a position to produce higher biomass under degraded corners of the farm (Tilahun Amede, 2003). Farmers were not interested to grow the Legume cover crops in the fertile corners, as they were allocated for food crops. The land they wanted to get improved are the border strips, the abandoned corners, steeply slopes and the barren land, where the land failed to produce any reasonable crop yield. But most of the Legume cover crops, with strong history in improving soil fertility, demand relatively fertile soils to establish, produce large amount of biomass and to fix atmospheric nitrogen. That is the reason why farmers selected crotalaria for improving degraded farmlands over mucuna, canavalia, tephrosia and vetch on individual farmer's field, Crotalaria was the best performing species regardless of soil fertility. Double cropping cereals with leguminous species have potential implications for the nitrogen requirement of and usage by the cereal component and, less frequently, on phosphorus use efficiency (Sinha et al 1983). The advantages of green manuring for increased crop productivity has also been reported elsewhere (Yeshanew and Asgelil, 1999). However, no work has been done so far in the region on the use and contribution of green manure to soil fertility improvement. The study conducted by Abebe Getu (2015) on the effect of green manure plants on sorghum Yield and soil fertility in eastern Amhara Region of Ethiopia revealed that there was statistically significant $(\mathrm{P}<0.05)$ difference in the grain yield of sorghum due to the effect of intercropping with the green manures. However, there was no significant $(p>0.05)$ effect of intercropping green manures on the biomass weight of sorghum (Table 5). combined analysis over the two experimental years as shown in Table 5 indicated that that the mean effect of intercropping green manures on the grain yield and biomass weight of sorghum were statistically significant $(\mathrm{p}<0.05)$. 
Tabe5. Effects of intercropping green manures on sorghum grain yield and biomass weight.

\begin{tabular}{|c|c|c|c|c|c|c|}
\hline & \multicolumn{2}{|l|}{2008} & \multicolumn{2}{|l|}{2009} & \multicolumn{2}{|c|}{ Combined over years } \\
\hline & Grain yield & $\begin{array}{l}\text { Biomass } \\
\text { weight }\end{array}$ & Grain yield & $\begin{array}{l}\text { Biomass } \\
\text { weight }\end{array}$ & Grain yield & $\begin{array}{l}\text { Biomass } \\
\text { weight }\end{array}$ \\
\hline treatment & \multicolumn{6}{|c|}{$\left(\mathrm{Kgha}^{-1}\right)$} \\
\hline Control & $3535.2 \mathrm{a}$ & 22217 & 3321.6 & 12431.5 & $3428.4 a$ & $17324.4 \mathrm{ab}$ \\
\hline Tephrosia v. & $3135.0 \mathrm{a}$ & 21366 & 3239.2 & 11500.7 & $3187.1 \mathrm{ab}$ & $16433.4 b$ \\
\hline Leucenea p & $3405.9 a$ & 23766 & 2717.7 & 12893.2 & $3061.8 b c$ & 1832 \\
\hline Tithonia d. & $2408.8 b$ & 20281 & 3033.1 & 11945.6 & $2783.4 \mathrm{c}$ & $16113.5 b$ \\
\hline GM & 3186 & 21907.8 & 3077.9 & 12192.8 & 3129.6 & 17050.3 \\
\hline CV\% & 6.6 & 7.03 & 9.4 & 4.7 & 8.7 & 6.3 \\
\hline LSD & 468.6 & Ns & Ns & ns & 349.4 & 1338.3 \\
\hline
\end{tabular}

Source: Abebe, 2015.

Treatments within a column followed by the same letter are not significantly $(\mathrm{p}>0.05)$ different; ns-non significant $(\mathrm{p}>0.05)$.

\subsection{Biogas Slurry}

In response to the need for addressing the adverse impacts of the increasing trend in biomass energy consumption in Ethiopia, the last three recent decades have witnessed heightened interest in mobilizing national and international efforts towards the development of more efficient cooking stove technologies and alternative sources of household energy. Biogas as an alternative to the use of biomass for energy was introduced in Ethiopia since late 1970s even though on a fragmented manner and with limited success in penetration of the technology (Kidane et al., 2007). According to a feasibility study on domestic biogas in Ethiopia (Getachew et.al., 2006), for example, from approximately 1000 biogas plants constructed since the 1970 s across the country only 40 percent were functioning at the time of the field visit.

In the same study (Getachew et al., 2006), the report indicated that at least over one million households in Tigray, Amhara, Oromiya and Southern Nations, Nationalities and Peoples regional states qualify for the installation of a domestic biogas plant. The domestic biogas technology attracted interest mainly due to consideration of the animal dung, the raw material that is plenty in many rural households in the country. After the establishment of the National Biogas Program Ethiopia in 2009, close to 859 biogas plants have been constructed and are in regular use. Out of the 859 functional biogas plants, 206 are found in Tigray Region, 143 are in Amhara Region, 330 in Oromiya Region and 180 are found in SNNP regional states (Claudia and Yitayal, 2011).

Application of bio-slurry in liquid and composted form alone at the rate of $20 \mathrm{t} / \mathrm{ha}$ or with full dose of chemical fertilizer at the rate of $10 \mathrm{t} /$ ha increase the yield of maize, soybean, wheat, sun-flower, cotton, ground nut, cabbage and potato in different percentages over the controls (IFPRI, (2010)). The study by Dhobighat and Painyapani, (2006) indicated that the use of bio-slurry increased the yield of rice and maize by 34 percent and the yield of wheat by 25 percent. The use of bio-slurry in different forms improved not only the quantity but also the quality of yield of the crops, vegetables and fruits as well as the disease resistance capacity of the plants (Krishna, 2001).

The study conducted by Yalemtshay Debebe (2013) Comparative study on the effect of applying biogas slurry and inorganic fertilizer on soil properties, growth and yield of white cabbage (Brassica oleracea var. capitata $\mathrm{f}$. alba) at Sebeta Hawas Woreda, South West Shewa zone Oromia Region indicated that combination of slurry compost and full dose of fertilizer (produced 38.4 percent higher yield than full dose of inorganic (Table 6). Likewise, the half dose of fertilizer with half ofthe slurry compost was 38.7 percent inferior to full dose of inorganic fertilizer with $80 \mathrm{q} /$ ha of slurry compost. This result is in line with the result of Singh et al. (1995) who reported that the combination of fertilizer and bio slurry significantly increased the yield of rice, corn, soybeans and okra. 
Table 6.Yield of cabbage due to application of bio-slurry and inorganic fertilizer

\begin{tabular}{|c|c|c|c|c|}
\hline Treatments & Treatment detail & $\begin{array}{l}\text { Yield } \\
\mathrm{Kg} / 9 \mathrm{~m} \\
2\end{array}$ & $\begin{array}{c}\text { Yield } \\
\text { (Ton/ha) }\end{array}$ & $\begin{array}{l}\text { Increment in yield } \\
\text { over control } \\
\text { (percent) }\end{array}$ \\
\hline $\mathrm{T} 1$ & Control & 14.4 & 160 & 0 \\
\hline $\mathrm{T} 2$ & $\begin{array}{l}\text { Recommended dose of inorganic fertilizer }(100 \mathrm{~kg} \\
\text { of DAP, } 50 \mathrm{~kg} \text { urea and } 50 \mathrm{Kg} \text { Murate of potash }) \text { per } \\
\text { hectare }\end{array}$ & 17.34 & 192.7 & 20.44 \\
\hline T3 & $1 / 2$ of recommended dose of inorganic fertilizer. & 16.5 & 183.3 & 14.6 \\
\hline T4 & Biogas slurry in liquid form $(80 \mathrm{q} / \mathrm{ha})$ & 19.5 & 216.7 & 35.4 \\
\hline T5 & Biogas slurry compost $(80 \mathrm{q} / \mathrm{ha})$ compost at $80 \mathrm{q} / \mathrm{ha}$ & 22.68 & 252 & 57.5 \\
\hline T6 & $\begin{array}{l}\text { Inorganic fertilizer (Recommended dose })+ \text { Biogas } \\
\text { slurry compost at } 80 \mathrm{q} / \text { ha }\end{array}$ & 24 & 266.7 & 66.7 \\
\hline $\mathrm{T} 7$ & $\begin{array}{l}\text { Inorganic fertilizer }(1 / 2 \text { Recommended dose })+1 / 2 \\
\text { Biogas slurry compost at } 80 \mathrm{q} / \mathrm{ha}\end{array}$ & 17.31 & 192.3 & 20.2 \\
\hline
\end{tabular}

Source: Yalemtshay, 2013

\section{Summary}

The government of Ethiopia has launched an agricultural package during the previous decade focused on a package of mineral fertilizer and high yielding varieties to increase crop production. However, farmers have been unable to using mineral fertilizer because of the high price, weak delivery, and a sharp drop of crop prices after harvests and unreliable rainfall. Instead farmers are highly inclined into locally available soil fertility management and yield increment practices including composting, green manure, and farm yard manure, crop residue and biogas slurry because they require high labor and low capital, which are risk avoidance strategies of Ethiopian farmers. Different relevant studies have been held across the county parts or regions to assess the effect different organic fertilizers like compost, farm yard manure, green manure, crop residue and biogas slurry application and use in experiment field and smallholder farming without upsetting their usual living. Results supposed to the benefit of farmers and come up with a policy briefing that policy makers give a better support for its implementation. The experiments conducted in different regions by different researchers like Maichew District of Tigray Region by Hailu Araya, Gozamen Woreda Eastern Gojam Amhara Region by Tadesse Dejene, haraghe zone Oromia region Easten Ethiopia by Zelalem Bekeko and Sirinka Earstern Amara rgegion by Abebe Getu and Yalemtshay debebe in Sebeta Oromia Region indicated that the application compost Farm yard manure green manure and Biogas slurry enhances different crop production and productivity by improving of soil physical and chemical property and also bring additional benefit in terms of minimizing inorganic fertilizers cost. Therefore this revised seminar visualized or tell us for the future as country level promoting of organic fertilizers in well-organized form is very important to enhance cereal crop productivity and there quality by improving soil and soil fertility issues.

\section{Reference}

Abebe Getu.2015. Effect of Adaptable Green Manure Plants on Sorghum Yields and Soil Fertility in Eastern Amhara Region of Ethiopia.J.Bio.Agri.Hlc.5(11).

Alemayehu Seyum, 2008. Decomposition of growth in cereal production in Ethiopia. Paper presented for DFID funded study "Understanding the constraints to continued rapid growth in Ethiopia: the role of agriculture". Ethiopia.

Ararsa G (2012). GIS based land suitability evaluation for sustainable agricultural development at Kuni (Sebale) watershade West Hararghe Zone, Oromia. M.Sc. thesis ,Mekele University, Ethiopia.

Asmelash, Arefayne (2001): Duk'e tefetro entayin kemeyin. Institute for Sustainable Development. Addis Ababa, Ethiopia

Claudia, B. and Yitayal Addis, (2011).Survey of biogas plants in four regional states of Ethiopia, SNV Ethiopia.

Cybernorth,(2004):Compostingguide:Compostingfundamentalshttp://www.cybernorth.com/gardening/compost.h tml

Dauda SN, Ajayi FA, Ndor E (2008). Growth and yield of water melon (Citrullus lanatus) as affected by poultry manure application. Journal of Agriculture for Social Science, 4: 121 - 124.

Debelle T, Friessen DK (2001).Effect of enriching farmyard manure with mineral fertilizer on grain yield of maize at Bako, western Ethiopia. Seventh Eastern and Southern African Maize conference 11th-15 ${ }^{\text {th }}$ February. pp 335-337.

Devi, R., Kumar, A. and Bishaw, D. (2007): Organic farming and sustainable development in Ethiopia. Scientific Research and Essay. Vol. 2(6): 199-203. Available online at http://www.academicjournals.org/SRE 
Dhobighat. C, Painyapani. T, (2006).Physico-chemical Analysis of Bio-slurry and Farm Yard Manure for Comparison of Nutrient Contents and other Benefits so as to Better Promote Bio-slurry, Yashoda Sustainable Development (P) Ltd, Final Report, Nepal.

Dong.H, and Li.Yu'e, 2010. Feasibility study: rural household biogas and conservation tillage CDM project development.

Edwards, S., Hailu Araya, and Zenebe Gebre-Egziabher, 2007. "Impact of Compost Use on Crop Production in Tigray, Ethiopia.” Rome: FAO, Natural Resources Management and Environment Department.

Elias, E. (2002): Farmers' perceptions of soil fertility change and management. ISD and SOSSahel International (UK). EDM Printing Press. Addis Ababa, Ethiopia.

Eyasu, E., 2002. Farmers' perceptions of soil fertility change and management. SOS-SAHEL, Institute for sustainable development, Addis Ababa, 252 p.

Fentaw Ejigu, 2010. Bio-slurry in Ethiopia: what is it and how to use it, Institute for Sustainable Development (ISD) and National Biogas Program Ethiopia Coordination Office. Addis Ababa, Ethiopia.

Ferdu, A., Demissew, K. \& Birhane A. 2002. Major insect pests of maize and their management: A review. p. 8996. In: Mandefiro Nigussie, D. Tanner and S. TwumasiAfriyie (eds.). Proceedings of the Second National Maize Workshop of Ethiopia. 12 - 16 November 2001 Addis Ababa, Ethiopia.

Getachew Agegnehu, Anigaw Tsigie and Agajie Tesfaye, 2012. Evaluation of Crop Residue Retention, Compost and Inorganic Fertilizer Application on Barley Productivity and Soil chemical Properties in the Central Ethiopian Highlands. Addis Ababa, Ethiopia.

Getachew Eshete (PhD), Dr. K. s, F. H, (2006). Report On The Feasibility Study Of A National Programme For Domestic Biogas In Ethiopia, SNV Ethiopia.

Gete Zelleke, Getachew Agwgnehu, Dejene Abera and Shahid R., 2010. Fertilizer and Soil Fertility Potential in Ethiopia: Constraints and opportunities for enhancing the system. IFPRI, Ethiopia.

Getnet, H. (2008): Evaluation of on-farm composting and compost quality at Ilala Gojo Welmera Wereda, Oromiya Region. Master Thesis, Addis Ababa University. Environmental Science Program.

Gruhn, P., Goletti, F., Yudelman, M. 2000. Integrated nutrient management, soil fertility and sustainable agriculture: current issues and future challenges. Food, Agriculture and the Environment Discussion Paper 32. International Food Policy Research Institute, USA, 38p.

Gutser, R., Ebertseder, T., Weber, A., Schrami, M. and Schmidhhalter, U. (2005): Short-term and residual availability of nitrogen after long-term application of organic fertilizers on arable land. J. Plant Nutr. Sci., 168: 439-446

Hailu Araya.2010. The Effect Of Compost On Soil Fertility Enhancement And Yield Increment Under Smallholder Farming - A Case Of Tahtai Maichew District - Tigray Region, Ethiopia.PhD Thesis.Faculty of Agriculture, University of Hohenheim.60-61pp

Heluf G (2002). Soil and Water Management Research Program Summary Report of 2000/2001 Research Activities. Alemaya Research Center, Alemaya University. Ethiopia, 95p.

Hoitink, A.J. and H.M. Keener. 1993. Science and engineering of composting: Design, Environmental, Microbiological and utilization Aspects. 728 printed pages.

IFPRI, (2010), fertilizer and soil fertility potential in Ethiopia, constraints and opportunities for enhancing the system, sustainable solution for enduring hunger and poverty. Skype: ifprihomeoffice, Washington, DC, USA. Pp 10-15.

Jagadeeswari, P.V. and K. Kumaraswamy, 2000. Long-term effects of manure fertilizer schedules on the yield and nutrient uptake by rice crop in a permanent manurial experiment. J. Ind. Soc. Soil Sci. 48: 833-836.

Jones MJ (1971). The maintenance of soil organic matter under continuous cultivation at Samaru, Nigeria. Journal of Agricultural Science, 77: 473 - 482.

Kidane Workneh, Williams Boers and Getachew Eshete, (2007).Implementation document for a national programme for domestic biogas in Ethiopia, SNV/Ethiopia.

Kikafunda, J., Bogale, T.T., Mmbaga, T.E., and Assenga, R.H. (2001): Legume fallows for maize-based cropping systems in East Africa: Screening legumes for adaptability, biomass and nitrogen production. Seventh Eastern and Southern Africa Regional Maize conference: 11-15 February 2001. pp. 319-323

Koppen, D and Eich, D. 1993. Influence from a 85-year differentiated organic manuring and mineral fertilization on soil fertility in the static experiment at Bad Lanchstadt. Soils and Fertilizers. 56 (1): 402.

Krishna, K (2001).Response to Bio-Slurry Application on Maize and Cabbage in Lalitpur District Final Report, Nepal.

Larson, W.E., Clapp, C.E., Pierre, W.H. \& Morachan, Y.B. 1972. Effects of increasing amounts of organic residues on continuous corn: II. Organic carbon, nitrogen, phosphorus and sulphur. Agron J. 64; 204-208.

Latham, M. 1997. Crop residues as a strategic resource in mixed farming systems. p. 181- 196. In: Renard, C. (ed.). Crop residues in sustainable mixed crop/livestock farming systems, CAB International. 
Lekasi, J.K., Tanner, J.C., Kimani, S.K. and Harris, P.J.C. (2001): Managing manure to sustain smallholder livelihoods in the East African Highlands. HDRA, Ryton-on-Dunsmore. ISBN 0905343

Leonard, D. 1986. Soil, Crop, and Fertilizer Use: A Field Manual for Development Workers. Under contract with Peace Corps. 4th edition revised and expanded. United State Peace Corps. Information collection and exchange. Reprint R0008.

Manna, M.C., Ghosh, P.K., Ghosh, B.N. and Singh, K.N. (2001): Comparative effectiveness of phosphateenriched compost and single superphosphate on yield, uptake of nutrients and soil quality under soybeanwheat rotation. Journal of Agricultural Science, Cambridge. 137: 45-54

Menale Kassie, Precious Zikhali, Kebede Manjur, and Sue Edwards, 2009. Adoption of Organic Farming Techniques Evidence from a Semi-Arid Region of Ethiopia.

Miner, F.D., Koenig, R.T. and Miller, B.E. (2001): The influence of bulking material type and volume on the in-house composting in high-rise, cage layer facilities. Compost Science and Utilization. 9(1): 50-59

Misganw.R.Beza.2014. Outcome of rich farmyard manure and inorganic fertilizers on grain yield and harvest index of hybrid maize (bh-140) at Chiro, eastern Ethiopia .J .Afr .Agro. 2(8): 194-199.

Mugwe, J., Mugendi, D., Kungu, J. and Mucheru-Muna, M. (2007): Effects of plant biomass, manure and inorganic fertilizer on maize yield in the Central Highlands of Kenya. African Crop Science Journal, 15(3): 111-126.

Ocio, J.A., Brookes, P.C. \& Jenkinson, D.S. 1991. Field incorporation of straw and its effects on soil microbial biomass and soil inorganic N. Soil Biol. Biochem. 23:171-176

Pimpini, F., Giardini, L., Borin, M. and Giaquinto, G. 1992. Effects of poultry manure and mineral fertilizers on the quality of crops. J Agric Sci 118:215-221.

Rekhi RS, Benbi DK, Bhajan S (2000). Effect of Fertilizers and OrganicManures on Crop Yields and Soil Properties in Rice-Wheat Cropping System: In Long-term Soil Fertility Experiments in Rice-Wheat Cropping Systems. pp.1- 6 .

Silva PSL, Silva J, Olivera FHT, Sousa AKF, Duda GP (2006). Residual effect of cattle manures application on green ear yield and corn grain yield. Horticultura Brasileira. 24: 166-169.

Sinha MN, Hampaiah R, Rai RK. 1983. Studies on phosphorus use efficiency in cereal-cereal rotations. Indian Journal of Agricultural Science 53, 893-898.

Smiciklas, K.D., Walker, P.M. and Kelley, T.R. (2008): Evaluation of compost for use as a soil amendment in corn and soybean production. Compost Science and Utilization. 16(3): 183-191.

SSNC (Swedish Society for Nature Conservation), (2008): Ecological in Ethiopia - Farming with nature increases profitability and reduces vulnerability. Stockholm, Sweden.

Tadesse Dejene .2011. Assessment Of The Practices And Aspects Of Farmland Management In Gozamen District, East Gojjam Zone, Ethiopia.Msc.Thesis,College Of Social Science ,Addis Abeba University.40-41pp.

Taffesse A., P. Dorosh and S. Asrat. 2011. Crop Production in Ethiopia: Regional Patterns and Trends, IFPRI Development Strategy and Governance Division/EDRI, ESSP II Working Paper 0016.

Tewabech, T., Getachew A., Fekede, A. \& Dagne, W. 2002. Maize pathology research in Ethiopia: A review. p. 97-105. In: Mandefiro Nigussie, D. Tanner and S. Twumasi-Afriyie (eds.). Proceedings of the Second National Maize Workshop of Ethiopia. 12 - 16 November 2001 Addis Ababa, Ethiopia.

The World Bank, 2010. Ethiopia-Agricultural Growth Program (AGP) Appraisal Stage, Project Information Document (PID), Report No: AB5416.

Tilahun Amede., 2003.Pathways for Fitting Legumes into the Farming System African Highlands: A Dual Approach. Soil Fert Net and CIMMYT-Zimbabwe, Hararre, pp, 21-30.

Tulema, B., Aune, J.B. and Breland, T.A. (2007): Availanility of organic nutrient sources and their effects on yield and nutrient recovery of tef [Eragrostis tef (Zucc,) Trotter] and on soil properties. J. Plant Nutr. Soil Sci., 170: 543-550

Van Duivenbooden, N. 1992. Sustainability In Terms Of Nutrient Elements With Special Reference To West Africa. Cabo-Dlo, Wageningen, The Netherlands.

Wahba, M.M. (2007): Influence of compost on morphological and chemical properties of sandy soils, Egypt. Journal of Applied Sciences Research, 3(11): 1490-1493

Wakene N, Abera T, Firesen DK, Deressa A, Dinsa B (2001). Evaluation of Compost for Maize Production under Farmer's Condition, Bako Agricultural Research Center, West Shoa, Ethiopia. Seventh Eastern and Southern Africa Regional Maize Conference. pp. 382 - 386.

Wakene N, Getahun F, Deressa A, Dinsa B (2007). Integrated Use of Organic and Inorganic Fertilizers for Maize Production. Utilization of diversity in land use systems: Sustainable and organic approaches to meet human needs. University of Rostock, Institute of Land Use, Justus-von-Liebig Weg 6, 18059, Rostock, German. pp.1 $-18$.

Wakene N, Heluf G, Friesen DK (2005). Integrated Use Of Farmyard Manure And NP Fertilizers For Maize On 
Farmers' Fields. J. Agric. Rural Develop. Trop. Subtropic. 106(2):131-141.

Yalemtshay Debebe.2013. Comparative study on the effect of applying biogas slurry and inorganic fertilizer on soil properties, growth and yield of white cabbage (Brassica oleracea var. capitata f. alba) at Sebeta Hawas Woreda, South West Shewa zone.Msc.Thesis.College of Natural Science,Addis Abeba University, Addis abeba.50pp.

Yeshanew A, Asgelil D. 1999. The effect of green manuring and application of fertilizer on the yield of bread wheat at Adet in Northwestern Ethiopia. pp 182-185. In: The tenth regional wheat workshop for Eastern, Central and Southern Africa. Addis Ababa, Ethiopia: CIMMYT.

Zelalem Bekeko.2013. Improving and sustaining soil fertility by use of enriched farmyard manure and inorganic fertilizers for hybrid maize (BH-140) production at West Hararghe zone, Oromia, Eastern Ethiopia.J.Afri.Reas.8(14):1218-1224.

Zinash, S. (2001): The role of livestock in crop-animal production system in Ethiopia. In: Paulos, D., Asgelil, D., Asfaw, Z., Gezahegn, A. and Abebe, K. (eds.): Advances in Vertisols management in the Ethiopian highlands. Proceedings of the International Symposium on Vertisol Management, 28 Nov. to 1 Dec. 2000, Debre Zeit, Ethiopia, pp. 53-58 